ROCZNIKI HUMANISTYCZNE

Volume 66 , issue $1-2018$

SELECTED PAPERS IN ENGLISH

DOI: http://dx.doi.org/10.18290/rh.2018.66.1-6e

PAWEŁ BOHUSZEWICZ

\title{
DANGEROUS LIAISONS, NECESSARY LIAISONS \\ ON THE “ALTERNATIVE” WAYS OF READING OLD POLISH TEXTS
}

As researchers of Old Polish literature, we try to avoid programmatic and holistic statements about the state of our discipline, because they are connected with difficulties of a twofold nature. We do not thematize our research on the basis of the principle on which we try not to write about Old Polish literature as a whole: both the first and the second area seem to be too huge to be judged sensibly. However, faced with the necessity of talking about them, we will always choose literature rather than researching it: speaking about literature, although it is cognitively risky, does not involve conflict with those whom we make the "object" of our statements.

This risk was boldly accepted by Agnieszka Czechowicz, the author of the article "Some remarks on the methodological compulsions in the study of Old Polish literature." I am not going to polemicize with the general

Dr PAwee Bohuszewicz - assistant professor at the Department of Old Polish Literature of Nicolas Copernicus University in Toruń; address for correspondence: e-mail: bohuszewicz@umk.pl

The Polish version of the article was published in Roczniki Humanistyczne vol. 59, issue 1 (2011).

${ }^{1}$ Roczniki Humanistyczne 56, is. 1 (2008): 7-16 (the references in my text to this article bear the number of the page in square brackets). In the same issue of Roczniki we can moreover find an article by Mirosława Hanusiewicz-Lavallee "Współczesne metody badań nad staropolską literaturą religijną" (17-37). Earlier comprehensive studies of Old Polish literature include the following texts: Janusz PELC, "Średniowiecze, renesans i barok w badaniach historycznoliterackich od roku 1918," in Rozwój wiedzy o literaturze polskiej po 1918 roku, ed. and introduction Janusz Maciejewski (Warszawa: Czytelnik, 1986); Tadeusz UlEwICZ, "W staropolszczyźnie dzieją się rzeczy ważne (dorobek badawczy pokolenia)," Ruch Literacki 7, No. 4 (1966): 161-77; Andrzej BOROWSKI, "Tendencje metodologiczne w najnowszych badaniach nad literaturą staropolską," Teksty Drugie No. 3 (1994): 78-83; Piotr WILCZEK, "Najnowsze tendencje w badaniach nad literaturą staropolską," in IDEM, Polonice et Latine. Studia o literaturze staropolskiej (Katowice: Wydawnictwo UŚ, 2007), 13-30. Let me at the end indicate my own article "Po co literaturze 
remarks on Old Polish literature. In a heuristically useful, succinct manner Agnieszka Czechowicz aptly demonstrates the uniqueness of old writing, involving the following: immersion in "the rhetorical, philosophical, artistic and theological achievements of Antiquity and Christianity" [8]; "existing in the order of art, i.e. regularity" [8] and an absence of clear-cut boundaries between fictional literature and other genres (such as pious, theological, didactic, and theoretical texts, among others). These statements, however, are marginal to the main thrust of the Author's article, which contains methodological recommendations on how to study Old Polish literature. Let me mention right at the start that in large measure I do not agree with them. Arguments in support of my discontent are the content of this article.

The author polemicizes with all attempts at applying "methods which we may call alternative" [11] for the study of Old Polish literature. These alternative methods for her include, first of all, Deconstructionism (without commentary, Agnieszka Czechowicz also mentions Gender Studies). The polemic is primarily based on the following assumption: the use of "alternative" methods in lieu of "a gradual discovery and recovery of the energy and beauty of old texts" [10], contributes to what can be called an "egocentric" study. The deconstructing reader or the one who applies methods known from Gender Studies, forgets the facts that languages are not suited for old texts (the Author observes that "Deconstructive readings of Old Polish texts make the impression of a significant strangeness along the researcher (reader)—text line" [12]). Thus does she forget about something fundamental for the history of literature: we are to study objects rather than ourselves, reconstruct rather than construct, interpret rather than create [see p. 11]. As a consequence, the "alternative methods" should be discarded as they deform the object of research and stay at the procedures that allow direct access to reality. Agnieszka Czechowicz brings them out of various "minor methodological comments accompanying specific studies on Old Polish literature" [13]:

They indicate that objects of culture, as documents of ideological concepts or a system of socially approved values, should be seen as real, unique and autonomous and that this recognition, evident in the respect for the native code of the objects under scrutiny, is a precondition for their proper reading; they confirm the conviction of the principal meaning of reconstruction, interpretation and valuation in the history of literature and indicate that the work of the scholar is a gradual discovery and recovery of the energy and beauty of old texts; they refer to the last

dawnej współczesna teoria?" [Why does old literature need a contemporary theory?], Litteraria Copernicana No. 2 (2008): 8-27. 
philosophical and theoretical manifestations of the twentieth century, recognizing the sense of internal intellectual reflection; they underline the necessity to refer to the sources and contexts of a literary work in the face of possible threats to the ideologization of discourse [14].

In short, the article by Agnieszka Czechowicz is another manifesto, following in the footsteps of Alina Nowicka-Jeżowa ("Komparatystyka i filologia. Uwagi o studiach porównawczych literatury epok dawnych"”2) and Mirosława Hanusiewicz-Lavallee ("Współczesne metody badań nad staropolską literaturą religijną"), which calls for the recognition of the importance of philology, but first and foremost for leading to a situation where it becomes the only way of accessing literary texts.

It is clear that philology is the fundamental discipline not only for the history of literature (until the mid- $18^{\text {th }} \mathrm{c}$. "one could not possibly dream about anything but philology in research"3), but also for historiography in general and in order to perpetuate the continuity (and the lack of it) of culture. Texts convey standards, values and worldviews that inform modern culture. Before, however, these standards, values and worldviews begin to impact on someone's identity in the stream of social discourse, someone must perform a task consisting - to use Bruno Latour's language-of "stabilizing" their vehicles. This is precisely what a philologist does. Interestingly, his tasks include the examination of the language of the text (at least this is what happened until linguistics emerged as a discipline in its own right), its content (along with the realities this content addresses), composition and generic qualities. ${ }^{4}$ In turn, the stages of a philologist's work include the "study" (critique), reconstruction and explication of the text. Stefania Skwarczyńska adds to this "individual characteristics,"5 while Alina Nowicka-Jeżowa calls for the re-introduction of the iudicium-the valuation, forgotten by early $20^{\text {th }}$ - century philology, the last stage of the procedure of a Renaissance philologist. ${ }^{6}$ The first two stages are used to establish the provenance and history, version, publication and authorship of the text,

\footnotetext{
${ }^{2}$ In Polonistyka w przebudowie. Literaturoznawstwo-wiedza o języku-wiedza o kulturzeedukacja. Zjazd polonistów, Kraków, 22-25 września 2004, ed. Małgorzata Czermińska et al., vol. II (Kraków: Uniwersitas, 2005). vol. II.

${ }^{3}$ Stefania SKWARCZYŃSKa, Systematyka głównych kierunków $w$ badaniach literackich, vol. I (Łódź: Łódzkie Towarzystwo Naukowe, 1948), 15.

${ }^{4}$ See ibidem, 20-24.

${ }^{5}$ See ibidem, 29.

${ }^{6}$ Komparatystyka i filologia, 350.
} 
to recreate its origin and plan, and to study its manuscripts. ${ }^{7}$ In turn, hermeneutics includes the following:

First, the genesis of the work should be examined using external and internal criteria, with particular emphasis on the source documentation, taking into account the provenance of the material and its various studies, analyzing the origin of individual motifs and confronting them with the writer's experiences, outlining the way they are composed, taking into account existing patterns, meticulously tracking down influences, carefully recording borrowings, considering contrasts and parallelism; sometimes an attempt is made to extract new and original elements using the "mutual illumination method." [....] However, there are no aspirations for psychological deepening and the ideological content is omitted. The history of ideas is practiced by researchers of philological orientation only in close connection with the history of words (K. Burdach), which, however, easily blurs the borders of ideological complexes and leads to an excessive growth of genetic tendencies, to a regressus in infinitum. ${ }^{8}$

As I have already indicated, I do not intend to debate the necessity of the presence of philology both in literary studies and culture in general, and I would deem as ill-advised anyone who would find it unnecessary. ${ }^{9}$ Texts simply need to be "stabilized" by means of many complicated and laborious procedures and, once stabilized, put into circulation by being printed or made available in the form of electronic documents, with which we are more

\footnotetext{
${ }^{7}$ Zofia MitoseK, "Metoda filologiczno-historyczna," in EADEM, Teorie badań literackich (Warszawa: Wydawnictwo Naukowe PWN, $\left.1995^{3}\right), 96$.

${ }^{8}$ Zygmunt ŁEMPICKI, "Literaturoznawstwo w Niemczech," transl. A. Lam, in IDEM, Wybór pism, vol. I (Warszawa: Wydawnictwo Naukowe PWN, 1966), 33-34—quoted after: Zofia MITOSEK, Metoda filologiczno-historyczna, 96.

${ }^{9}$ This is how Skwarczyńska defends philology, and she is well aware of its limitations: "The main frame of the research method of philology has remained unshaken. The principles of criticism, e.g. the principles of text criticism, are immovable, as are the principles of hermeneutics. No one has come up with anything better in these areas.

Contrary to reservations, no student can be initiated into any literary research methodology without the introduction into this 'abc,' which is the fundamental philological method. We use this method, even unconsciously, in all research in our field. It has become a part of us and its necessity is obvious.

Another merit is the development, the final development of certain methods in certain areas of research. There is only one possible technique of criticism of written records and of scientific edition: the philological one.

Finally, there is a contribution that is still too little appreciated. Philology has developed a researcher's ethos. If today we demand from a researcher not only erudition and skill, but also accuracy and responsibility in work, a high regard for science and for the service to it, and meticulous diligence - it is this ideal of a scholar that philology has developed" (Stefania SKWARCZYŃSKA, Systematyka głównych kierunków w badaniach literackich, 38).
} 
and more often confronted today in this era of the Internet revolution. The principles of this "stabilization" and publication are still under discussion, but it is obvious to me that Renaissance or $19^{\text {th }}$-century positivist philology, with its ideas of "collecting, segregating and comparing" with a view to determining the best possible version of the text, can serve as a model here. ${ }^{10}$ It is hard, however, not to regard suspiciously the positivist idea of philological hermeneutics, the positivist idea of reading-especially today, in the era of the anti-positivist turn. ${ }^{11}$ It is easy to notice that the model of reading proposed by the continuators of the interpretative assumptions of philology is defined by the typically positivist fetishization of factography, objectivism, anti-axiology, genetism and intellectualism. ${ }^{12}$ Why am I talking about fetishization? Because none of these characteristics is bad in itself; it is bad to think however, that we can only base our communication with texts on these texts only. The same applies to philology: contrary to what Agnieszka Czechowicz implies, "alternative methods [...] in methodical terms distrust [...] philology" [12] not because they regard philology as something to be invalidated, but because they would like to curb its nearly absolute rule.

The dominance of the philological paradigm in the study of Old Polish literature is confirmed by a passage of the aforementioned article by Mirosława Hanusiewicz-Lavallee, quoted below. Although the author writes about the research of religious literature, it seems to me that her words have a multidisciplinary range and summarize very well what most Old Polish literary scholars usually do with the texts they are investigating:

The obviousness of what is declared [in the titles of the songs-P.B.], encourages us to adopt a genetic orientation of our research, to ask who wrote what, when and for whom, and also what it all is a translation, alteration or paraphrase of. Once this has been established, the next step leads to explication, breaking the code of a receding culture, explaining unobvious meanings and again-building another level of cultural and literary dependencies. This research procedure, apparently simple, proved to be the most fruitful, creative and real, so to speak, for the knowledge of Old Polish religious literature. ${ }^{13}$

\footnotetext{
${ }^{10}$ Alina NowiCKA-JEżowa, Komparatystyka i filologia, 350.

${ }^{11}$ I am referring here to the title of the text by Andrzej Szahaj ("Zwrot antypozytywistyczny dopełniony [zamiast wstępu]," in Filozofia i etyka interpretacji, ed. Adam F. Kola, Andrzej Szahaj (Kraków: Universitas, 2007).

${ }^{12}$ According to Nietzsche, these were the characteristics of his contemporary history studies. See Michał P. MARKOWSKI, Nietzsche. Filozofia interpretacji (Kraków: Universitas, 2001²), 202-04.

${ }^{13}$ Wspótczesne metody badań nad staropolska literatura religijna, 18.
} 
Of course, it is not that all researchers of Old Polish literature act in the manner described by Mirosława Hanusiewicz-Lavallee. In a nutshell, I would like to say that there are two methods of dealing with literature among them, which coincide with the tendencies that characterize modern literary studies, and which Ryszard Nycz described in the following way:

In the history of modern literary studies one can distinguish two basic tendencies. The first aims to make national literary research an exponent, guardian and explorer of contemporary cultural traditions and an interdisciplinary center of the entire (national) humanities. The second strives primarily to achieve the status of modern science, i.e. an autonomous discipline with its own subject matter and its own methodology, which by the degree of accuracy, professionalism and individuality corresponds to the status of other humanities. ${ }^{14}$

I have elsewhere described in detail their manifestation in research on Old Polish literature, ${ }^{15}$ so I will not comment on the quote in extenso here. Let me add, though, that representatives of both tendencies share two fundamental interpretative assumptions: a) interpretation should offer as little decontextualization as possible, i.e. it should explicate; b) texts are to be examined rather than read. These views, I think, result from the previously adopted positivist philosophy of literature, according to which literature would be a group of objects rather than an articulation of the world's experience, an articulation that cannot be separated from the situation of its reception.

What does it mean that the representatives of the two above paradigms are united by the conviction that it is necessary to limit decontextualization within the framework of interpretation practice? Let's start the answer to this question with the following definition of interpretation:

\footnotetext{
${ }^{14}$ O przedmiocie studiów literackich-dziś, in: Polonistyka w przebudowie. Literaturoznawstwo-wiedza o języku-wiedza o kulturze-edukacja. Zjazd polonistów, Kraków, 22-25 września 2004, vol. I, ed. Małgorzata Czermińska et al. (Kraków: Uniwersitas, 2005), 15-16.

${ }^{15}$ Paweł Bohuszewicz, Po co literaturze dawnej wspótczesna teoria? One important reservation is in order: in my article, out of necessity I referred to Nycz's terminology, according to which the first option would be a philological one. In the present text I equate philology with the current emphasizing the autonomy of literature.

The reference to the division of Old Polish literature research should be supplemented by a list of outsiders, i.e. those who remain outside this division. These would include, for example, Antoni Czyż, Aleksander Nawarecki, Kwiryna Ziemba (see Piotr WilczeK, Najnowsze tendencje w badaniach nad literatura staropolska, 24-25) and Dariusz Cezary Maleszyński.
} 
By interpretation I mean here the possibility of formulating any statement, as well as the effect of this operation, i.e. a text whose writing was provoked by the existence of another text. I can also say otherwise, and it is rather the second "definition" that is closer to me. The interpretation, which is indicated by the etymology of the word, which is too often forgotten, is not a transfer into a different context (inter-), and at the same time making it available (praestare, from which the French preter originates) to other users. Interpretation is therefore impossible without even the slightest decontextualization, a transfer which, while allowing access to the text, also enables the text to be moved, transformed, transferred into a different communication space. ${ }^{16}$

In order to explain the decontextualization Michał Paweł Markowski refers to, let us use an example of earlier interpretations of $\mathrm{Na}$ oczy królewny angielskiej... by Daniel Naborowski. All of them treat the poem as a representative of the poetics of conceit. Naborowski's masterpiece is to provoke amazement through its bold metaphors invented by the poet to refer to the beauty of the princess's eyes and through its elaborate construction. Its first, "ascending" part, consists of the search for similarities between the eyes and specific notions. The second, "descending" one is dedicated to seeking differences between them, while the third section sums up all the invoked entities and pronounces that the eyes are all of them simultaneously. The description of this construction is done by referring to the original context: historical poetics together with rhetoric and logic, thanks to which we can, for example, state that Naborowski's poem is an example of a Petrarchan poem, ${ }^{17}$ its construction being based on the figures of correctio, ${ }^{18}$ congeries (gathering) ${ }^{19}$ and summation, ${ }^{20}$ resembling "the Sophist syllogism of a sorites, invented by philosophers from Megara, where a proposition being the conclusion of one syllogism, together with the next proposition, is a premise for the next, and so on, and the line of reasoning inevitably concludes with paradoxes." 21 These statements constitute an articulation of the alleged sense

\footnotetext{
${ }^{16}$ Michał P. MARKOwSKI, "Pieczołowite egzegezy i demoniczne użycia," in IDEM, Efekt inskrypcji. Jacques Derrida i literatura (Kraków: Homini, 2003²), 402.

${ }^{17}$ See Krzysztof Mrowcewicz, Trivium poetów polskich epoki baroku: klasycyzm-manieryzm-barok (Kraków: Instytut Badań Literackich, 2005), 142.

${ }^{18}$ Dariusz CHEMPEREK, "Umyst przecię z swojego toru nie wybiega." O poezji medytacyjnej Daniela Naborowskiego (Lublin: Wydawnictwo UMCS, 1998), 45.

${ }^{19}$ Janusz K. GoliŃSKI, Unitas et varietas. Szkice o piśmiennictwie polskiego baroku (Warszawa: Towarzystwo “Ogród Ksiąg,” 2007), 150.

${ }^{20}$ Jadwiga KotARSKA, Erotyk staropolski. Inspiracje i odmiany (Wrocław: Wydawnictwo PAN, 1980), 193.

${ }^{21}$ Krzysztof Mrowcewicz, Trivium poetów polskich epoki baroku, 143; see also: Barbara FALĘCKA, Sztuka tworzenia. Podmiot autorski w poezji kunsztownej polskiego baroku (Wrocław:
} 
of Naborowski's work which, like any articulation, is possible thanks to decontextualization, i.e. the transfer of meaning from the context of the language of the poem itself into the context established by the language of concepts of historical poetics. Why, however, has the sense of the poem been transferred to this particular context rather than to another one? And why is the historical and literary context the most important for the invoked interpretations? This is because their authors placed themselves in the role of literary historians, assuming that their primary task is both the analysis of the text (invariably "always a dissection of a non-standard whole into standard elements", or "normalized and typical components that recur within certain established types of literature"22) and the explication of the sense, which would be aligned with the intention of the author, even if it is no longer the author of the text...

The differentiation between the intentio auctoris and the intentio operis comes from Umberto Eco, who believes that the text tells us not only "what the author wished to say" but also what it wanted to say of itself. He backs up his reasoning with the following anecdote. A reader asked him what he meant by placing a remark made by William at the end of the trial in The Name of the Rose ("'What terrifies you most in purity?', Adso asks. And William answers: 'Haste"') with the remark made on the very same page by Bernard Gui ("Justice is not inspired by haste, as the Pseudo Apostles believed, and the justice of God has centuries at its disposal" 23 ). "The reader rightly asked me what connection I had meant to establish between the haste feared by William and the absence of haste extolled by Bernard. I was unable to answer", because he actually added the conversation between Wilhelm and Adso already in the galleys, for purely aesthetic reasons. As Eco claims: "I needed to insert another scansion before giving Bernard the floor again. And I completely forgot that, a little later, Bernard speaks of haste." The text, then, created this connection of itself:

\footnotetext{
Zakład Narodowy im. Ossolińskich, 1983), 22; Dorota GosTYŃsKA, Retoryka iluzji. Koncept w poezji barokowej (Warszawa: Instytut Badań Literackich PAN, 1991), 159; Andrzej BorowsKI, "Daniel Naborowski-wiersze wybrane," in Lektury polonistyczne. Średniowiecze-renesansbarok, vol. I, ed. Andrzej Borowski, Janusz S. Gruchała (Kraków: Universitas, 1994), 289.

${ }^{22}$ Janusz SŁAWIŃSKI, Analiza, interpretacja $i$ wartościowanie dzieła literackiego, in IDEM, Prace wybrane, ed. Włodzimierz Bolecki, vol. IV: Próby teoretycznoliterackie (Kraków: Universitas, 2000), 10.

${ }^{23}$ Umberto Eco, The Name of the Rose, transl. William Weaver (Boston-New York: Mariner Books, 2014), 543.
} 
The text is there, and it produces its own effects. Whether I wanted it this way or not, we are now faced with a question, an ambiguous provocation; and I myself feel embarrassment in interpreting this conflict, though I realize that a meaning lurks there (perhaps many meanings do). ${ }^{24}$

Let us reiterate: the text is there, and it produces its own effects, and an utterance is a certain event. This quality of the text is no doubt comprised of its contextual character. The text must enter into a dialog with some extrinsic systems so that it can start to signify in the first place. The dialog cannot be confined and constricted; there is no situation where someone provides a "complete" reading of Kochanowski. Why? Because all texts are "osmotic," ${ }^{25}$ nearly indefinitely. They are open, their openness is limited solely by the semantic potential and involves not only the contexts envisaged by the author but also those which come from nowhere, and whose existence can be signaled by the "alternative methods" criticized by Agnieszka Czechowicz (let me add, parenthetically, that the openness of the text is indicated not only by the "mad" post-Structuralists, but also by more traditionally oriented thinkers, such as Eco, Mikhail Bakhtin and Charles Sanders Peirce, one of the founders of modern semiotics ${ }^{26}$ ).

Bearing in mind what the intention of the text and textual osmosis are, let us return to Naborowski's poem. There is no denying that it is based on the figures of correctio, congeries and summatio. I must also note at the same time that the poem gains when we read it far more seriously than it deserves as an example of conceit in poetry: as a literary attempt to prove that to pin down a metaphor is impossible. I have done it before, in my article “"Niezgodna niezgodność': metafora jako farmakon i nieudana próba wyjścia z impasu," where I resorted to The Pharmakon, one of the betterknown earlier texts by Jacques Derrida. ${ }^{27}$ Thanks to Derrida's interpretation of this Platonic notion I, hopefully, managed to get deeper into the semantics of Naborowski's text. The impossibility of establishing a single metaphor of the princess's eyes stems from the very same reason why pharmakon is pharmakon: a sum total of opposites. Plato, according to Derrida, believes

\footnotetext{
${ }^{24}$ Umberto ECO, "Between Author and Text," in Interpretation and Overinterpretation, ed. Stefan Collini (Cambridge: Cambridge University Press, 1998), 76-77; emphasis P.B.

${ }^{25}$ On textual osmosis see Wojciech Kalaga ("Granice tekstu-mgławice tekstu," Teksty Drugie No. 4 (1998): 11).

${ }^{26}$ See ibidem, passim.

${ }^{27}$ Paweł BohUszewicz, “'Niezgodna niezgodność'. Metafora jako farmakon i nieudana próba wyjścia z impasu,” Ruch Literacki No. 4-5 (2009): 313-25.
} 
that writing is simultaneously beneficial and inimical for human beings as on the one hand writing "repairs and produces, accumulates and remedies, increases knowledge and reduces forgetfulness, 28 while on the other hand writing introduces a distance between man and himself as he subjects his own memory to something other than himself, ${ }^{29}$ but at the same time it is something else: "under pretext of supplementing memory writing makes one even more forgetful; far from increasing knowledge, it diminishes it." 30 Created for benevolent purposes writing adds of itself; it seems something unexpected, countering what it was initially supposed to serve. In Of Grammatology, Derrida called this something supplément, which is:

exterior, outside of the positivity to which it is superadded, alien to that which, in order to be replaced by it, must be other than it. Unlike the complement, dictionaries tell us, the supplement is an "exterior addition" (Robert's French Dictionary). ${ }^{31}$

Derrida's supplément does not so much fill in but replaces and infects what was to be filled in. Is this not the case with Naborowski's masterpiece? The poet, trying to provide a description of beauty, quotes notions which he subsequently rejects, aware of the logic of both insufficiency and Derridian "supplementarity": each next metaphor brings something that initially, at the moment of invoking it, was unpredictable and which is the opposite of intentional sense.

What do we gain by interpreting this poem via "notions that did not fit the then horizons of penning and reading texts at all" ?" In other words, what do we accomplish by a radical decontextualization with a view to arriving at the intention of the text, which is not identical with that of the author? Before we answer the above questions let us identify what it is we do not lose. Definitely, we do not undermine earlier interpretations: invoking Derrida, I do not invalidate the statements made by Dariusz Chemperek, Janusz K. Goliński, Jadwiga Kotarska, and Krzysztof Mrowcewicz. I can only nod my head when reading their texts, all the more so that their research

\footnotetext{
${ }^{28}$ Jacques DerRIDA, "The Pharmakon," in IDEM, Dissemination, transl. with an introduction and additional notes by Barbara Johnson (London: The Athlone Press, 1981), 97.

${ }^{29}$ Ibidem, 98.

${ }^{30}$ Ibidem, 100.

${ }^{31}$ Jacques DeRridA, Of Grammatology, transl. G.C. Spivak (Baltimore: John Hopkins UP, 1997), 146.

${ }^{32}$ Krzysztof ObRemski, "Bitwa i polowanie w 'Kronice polskiej' Anonima zwanego Gallem. Relacje świata ludzkiego ze światem zwierząt,” Pamiętnik Literacki No. 3 (2008): 5.
} 
facilitated mine: I would not be able to write that Naborowski's poem is based on conceits if I had not read that it follows the rules of conceit poetry; it was only the identification of this relation that helped me to construct my own. Therefore, I don't approach this text like a "typical" Deconstructionist, i.e. someone interested in destroying (previous interpretations and culture in general) or, at best, perpetuating his own identity, ${ }^{33}$ but as a... philologist, inasmuch as I enter into a dialog with my predecessors and the text they interpreted. Why this urge for dialog, however? Why the need to express the sense of the work in the context unplanned by it, in a language other than its language ? $^{34}$ There are at least two valid answers to the above questions: one connected with general methodology and a hermeneutic one. Both stem from the earlier adopted philosophy of a literary text, according to which the text has "osmotic" propensities, i.e. enters into relations not only with the original contexts, but also with those that come from elsewhere.

1. Theoretical languages of description, which Agnieszka Czechowicz criticizes in her text-I will remind you that this is a criticism of Deconstruction and Gender Studies - are languages created today, yet their scope is not limited to the present; on the contrary: inscribed in them is the will of

\footnotetext{
${ }^{33}$ This perception of Deconstruction has recently been opposed by Markowski ("Dekonstrukcja”, in: Anna BurZYŃska, Michał P. MARKowski, Teorie literatury XX wieku. Podręcznik, (Kraków: Znak, 2006), 369-72).

${ }^{34}$ When I asked this question, I remembered the following words of Henryk Markiewicz: "In the game of communication between the text and the interpreter, two strategies are revealed today. The first one is the identification strategy, when the researcher identifies himself with the work, tries to provide its equivalent, speaks its language, and constructs its interpretative paraphrase. The second strategy could be called 'esoteric': it reveals senses hidden from an average-prepared recipient, referring to various philosophical and theosophical categories, etc., not necessarily known to the author of the text under scrutiny. In the latter case, I don't want to say that anything goes, but more and more is permitted. Jokingly speaking, the contemporary researcher has followed in the footsteps of a theatre director and, like him, has bold "ideas"” (Henryk MARKIEwICZ, "Zrzędność bez przekory," Teksty Drugie No. 2 (1990): 94-95). The division applied by Markiewicz is referred to by Krzysztof Obremski, who divides the art of seeking contexts in the history of literature into "classical" and "romantic": "The one who closes the analyzed text in tradition and thus ends its work, i.e. the Classic, follows the principle 'everything has already been said, if not in the Bible or by Homer, then a little earlier or a little later.' That is why in his literary analyses the Classic will stop at inscribing the examined text into tradition, which will exhaust the questions posed by the text as a context. On the other hand, the one who "opens" the subject of his historical-literary analyses towards the future, i.e. the Romantic, is guided by the principle that 'the present explains everything.' That is why the Romantic will find almost everywhere, if not Jung or Habermas, at least personalism or the philosophy of dialogue" (Krzysztof OBREMSKI, "O intertekstualności badań historycznoliterackich," AUNC. Filologia Polska XLI (1993): 114). I consider both these divisions to be cognitively valuable, but I cannot agree with the evaluation present in them.
} 
universality and supra-historicism. However, the same applies to the more traditional notions, which are used by each of us. Terms such as storyline, narrator, lyrical subject, and structure do not refer exclusively to contemporary literature, but to all literature. Should we renounce them because they are alien to the consciousness of old authors? I do not believe that the Author of "Some remarks on the methodological compulsions in the studies on Old Polish literature" wished to do so. Yet this is the logic of her text: the languages of description, worked out by Gender Studies and Deconstructionism, are inappropriate because they come from outside the original context, but also the terms I mentioned above come from outside the space that was not delineated by them, so these should also be considered inappropriate.

But why use them? The simplest answer is: if we assume that thanks to the newest languages of description we understand literature better (and not only the newest, just as the modern theory of literature does not refer only to contemporary literature!), then we gain a better understanding of old texts. Thanks to Derrida's theory of the pharmakon I can better understand what happens in Naborowski's text. Thanks to anthropology I can better relate to what transpires in Gallus Anonymus' Polish Chronicle and thanks to phenomenology and hermeneutics I can better appreciate Kochanowski's oeuvre, even if Naborowski, Gallus Anonymus and Kochanowski had no idea about the pharmakon, anthropology, phenomenology, and hermeneutics. These interpretations allow us to update the semantic potential existing in the interpreted texts, which we would not have a chance to see if we respected only the author's intentions, and which we can see thanks to the "osmotic" nature of the text. These interpretations allow us to ask the text such questions which, although justified-i.e. conditioned by the "osmotic" nature of the text-were not anticipated by the authors of the text. This is perfectly illustrated by the following passage from Wayne Booth's book (I don't want his humorous poetics to provoke thinking that the questions that appear in it are not serious questions):

What do you have to say, you seemingly innocent child's tale of three little pigs and a wicked wolf, about the culture that preserves and responds to you? About the unconscious dreams of the author or folk that created you? About the history of narrative suspense? About the relations of the lighter and the darker races? About big people and little people, hairy and bald, lean and fat? About triadic patterns in human history? About the Trinity? About laziness and industry, family structure, domestic architecture, dietary practice, standards of justice and revenge? About the history of manipulations of narrative point of view for the creation of sympathy? Is it good for a child to read you or hear you recited, night after night? Will stories like youshould stories like you-be allowed when we have pro-duced our ideal socialist 
state? What are the sexual implications of that chimney — or of this strictly male world in which sex is never mentioned? What about all that huffing and puffing ? $^{35}$

2. According to Agnieszka Czechowicz, "the most important, or one of the most important features of culture is its continuity, i.e. the continuum of its duration, the values that constitute it, the ideas that influence its creators, and the changeability and redefinition of these ideas" [10]. I can only partly subscribe to this opinion as I believe rather that European culture is a "discontinuous continuity," made up by two levels: the "deep" diachronic and the "superficial" synchronic level. On the first level, true, culture is continuity and includes such "universals" as the ability to create and even certain concrete features of stories, symbols, customs, beliefs, etc. (I leave unanswered the question whether, since these skills are timeless and universal, they are cultural or natural?). On the second level culture develops not only through evolution, but also through revolutions and ruptures that clearly contradict the idea of the continuity of culture. Romanticism was the most important and radical rupture in modern European art. It is during this time that a process takes place, which is a denial of all that was constitutive of old literature and that Agnieszka Czechowicz excellently summarizes: a division into fiction and functional literature; a break with the didactic and theological function of literature; a departure from the order of art, i.e. regularity, determined by the poetics and classical rhetoric. ${ }^{36}$

However, why am I writing about this in the context of the just proposed postulate to research/read Old Polish literature, transcending its own language? Since the rupture of Romanticisim has prepared the space in which we study and read old texts, thanks to this we can ask these and not other questions as researchers, thanks to this we can also like it or not-as readers. I come here to the previously formulated statement that the community of researchers of Old Polish literature is characterized by the conviction that

\footnotetext{
${ }^{35}$ Literary Understanding: The Power and Limits of Pluralism (Chicago: The University of Chicago Press, 1979), 243-quoted after: Jonathan Culler, "In Defence of Overinterpretation," in Interpretation and Overinterpretation, 113-15.

${ }^{36}$ It should be remembered, however, that the awareness recognizing culture in terms of a dispute between the "new" and the "old" is not an invention of Romanticism since "in almost the entire history of Greek and Roman literature and culture, from Homer's Alexandria critique to Tacitus' dialogue about speakers, such claims of the 'newer ones' always stirred up a dispute with the worshippers of the 'old,' and inevitably the dispute petered out on its own in the course of history" (Hans Robert JAUSS, "Tradycja literacka a dzisiejsza świadomość nowoczesności," in IDEM, Historia literatury jako prowokacja, transl. Małgorzata Łukasiewicz, afterword Kazimierz Bartoszyński. (Warszawa: Instytut Badań Literackich, 1999), 10).
} 
works should be studied and not read. What does it mean to read, however? It means that we do not treat what we read as an object, as something materially different from ourselves. A hermeneutic opposition to this approach was expressed by Paweł Dybel as follows:

anyone who comes into contact with the sense of cultural testimonies of the past cannot treat it as an originally external, alien "object" to which he could be completely distanced, because the meaning, the "object" he talks about, always refers to it, questions it and hits it. ${ }^{37}$

To read means to abolish the borderline between oneself and what is read, through the "application" of "the meaning of old for the scholar's 'present' self-comprehension in a particular point of history. This moment testifies to the truthfulness of this experience." 38 According to Gadamer, whose idea I invoked in the interpretation of Paweł Dybel, in a humanistic experience one cannot possibly erase this experience. ${ }^{39} \mathrm{I}$ believe the reverse is the case: the history of the humanities shows that we dedicate ample time to this erasure, that we manage quite well and, moreover, build on it the identity of our discipline as science and of ourselves as scholars. Naturally this applied to the science of Old Polish literature: it remains a science inasmuch as it separates the subject and the object and through this separation builds the identity of the former as a scholar and of the latter as a set of old texts.

Here, again, I am not claiming that one should kill philology in any form, be it connected with the Renaissance or positivism. Nor will I claim that we should abolish the above division. If the separation exists, it shows that its existence paid off. To a certain extent, I can relate to the statement made by Juliusz Kleiner, who wrote that Diltheian and post-Diltheian humanities wants to speak about the morphology of spiritual life and "forgets that in art, morphé is a shape rather than a supra-individual essence of spiritual attitudes." ${ }^{40}$ A literary text is not, however, solely an object, the Kleiner shape, as it is moreover a record of someone's experience of the world, which reaches me, who also experience this world in some manner. I wrote that maintaining the distinction between the subject and the object must have

\footnotetext{
${ }^{37}$ Granice rozumienia i interpretacji. O hermeneutyce Hansa-Georga Gadamera (Kraków: Universitas, 2004), 145.

${ }^{38}$ Ibidem, 101.

${ }^{39}$ See ibidem, 95.

40 "Historyczność i pozaczasowość w dziele literackim," in IDEM, Studia z zakresu teorii literatury (Lublin: Towarzystwo Naukowe KUL, 1956), 14.
} 
been worthwhile if it has been maintained for so long; it facilitates literature study: purely intellectual and non-axiological "stabilization" of texts and their explanation. However, in certain situations it is also worthwhile abolishing this distinction, as we are convinced by Nietzsche, Heidegger, Gadamer, Derrida, Stanley Fish, Richard Rorty, and Markowski.

So, what do we gain by reading a literary text whose author does not hide behind the method, but on the contrary discovers that he has a certain "I" immersed in values, worldviews, in short, in what we call culture? Getting to know a certain network: the horizon of the work and the horizon of the reader melted into one: a text read by someone. Paweł Dybel perfectly shows why it would be valuable to get to know such a network. In the aforementioned monograph on Gadamer, Paweł Dybel comments on the works of Andrzej Walicki and Maria Janion concerning Polish Romanticism, writing that their meaning is not determined by a methodologically correct reconstruction of the political and philosophical views of the leading writers of that period, but by the fact that:

\begin{abstract}
They bring a comprehensive reading of the achievements of this epoch, made from a very specific, particular research perspective, behind which there are specific superstitions [Dybel means here, of course, "pre-judice" in Gadamer's terms - as a pre-judgement (das Vorurteil) - P.B.]. [...]. The value of these works is determined by the fact that their authors, writing about this distant historical epoch on the basis of what is available to them, suggestively demonstrate how deeply present in the political thought of the most outstanding Polish Romantics was a very modern understanding of the ideals of democracy and religious tolerance and thus how far the patriotic ideas they proclaimed had nothing to do with narrowly understood nationalism and traditionalism. In a word, with time these works gained the rank of "classic," because they contain the most individual vision of the world of their authors, the world in whose name they appear in them. They do not appear from the position of an abstract timeless subject of research but are organically present in their discourse in the whole historical particularity of their thinking. ${ }^{41}$
\end{abstract}

It is not about what the hermeneutics scholars are accused of by their opponents, and what can also be seen in Agnieszka Czechowicz's diatribe against Deconstructionism, namely that they aspire primarily to expose their own "identity" (although, of course, there are also such scholars). Nor is this related, I believe, to the exposure of one's own, individual self, of one's own

\footnotetext{
${ }^{41}$ Paweł DyBeL, Granice rozumienia i interpretacji. O hermeneutyce Hansa-Georga Gadamera [The limits of understanding and interpretation. On the hermeneutics of Hans-Georg Gadamer] (Kraków: Uniwersitas, 2004), 129-30.
} 
existence, but is meant to reveal a certain cultural self, understood as a perspective embedded in a broader context, from which one can see. Revealing this perspective in the works of Maria Janion and Andrzej Walicki is valuable because it helps to establish a link between the present and the tradition of this perspective, because it shapes Romanticism no longer as an external "object" of research, but as a certain sense which, being in fact a part of ourselves, "beckons to" us and "hits" us. ${ }^{42}$

The reverse is also the case: the revelation of a historical perspective which serves as a vantage point allows us to see clearly that the sense, while it "beckons us," it cannot be related to. Perhaps, barring the greatest authors, there is a huge gap between Old Polish literature and us, a rupture started in the 18 th century by modernity $?^{43}$ Therefore, we will be unable to make Figliki by Mikołaj Rej, emblems by Aleksander Teodor Lacki and Baroque romances part of our "worldview." The answer to the question will depend on both the features of literature itself and on the worldview of the persons answering, on whether or not they identify with modernity or not. For example, the response offered by the authors publishing in Fronda magazine will be negative; they will say that they see no gap as they continually live in a spiritual space delineated by pre-modernity. ${ }^{44}$ For me, as a person identifying rather with the legacy of the secularized post-Renaissance culture, the gap will be huge. Despite this very sharp difference between our cultural identities, I prefer to read their essays to another text defining the influence and showing "who derived what from whom." This is because of the same reason why Paweł Dybel likes to read the works of Maria Janion or Andrzej

\footnotetext{
${ }^{42}$ See ibidem, 145.

43 "The question about the origin of the modern world has been recently addressed by historians of ideas and historians of society and it seems that the decisive change of perspective could take place in the time saddle between the mid- $18^{\text {th }}$ century and the mid- $19^{\text {th }}$ c., with the French Revolution as its peak. [...] [At that time-P.B.] 'old words gained a new meaning, which as we come closer to our times, no longer requires explanation'” (Hans Robert JAUSS, "Proces literacki modernizmu od Rousseau do Adorna," transl. Piotr Bukowski, in Odkrywanie modernizmu, ed. and introduction Ryszard Nycz (Kraków: Universitas, 2004), 31-32. The words quoted by Jauss come from R. Koselleck).

${ }^{44}$ See e.g. Krzysztof KoEHLER, "W rytmie godzinek, na rosyjskim trupie," Fronda No. 4/5 (1995): 287-307; IDEM, "Piotr Skarga, czyli witajcie w naszych czasach," Fronda No. 9/10 (1997), 7-21; IDEM, “Kościół, reformacja, dialog," Fronda No. 13/14 (1998): 28-47; IDEM, "Wstęp," in "Stuchaj mię, Sauromatha." Antologia poezji sarmackiej, ed. Krzysztof Koehler (Kraków: Arcana, 2002); Paweł Lisicki, "Mroczne dziedzictwo oświecenia," in IDEM, Nie-ludzki Bóg. Eseje (Warszawa: Fronda, 1995); Wojciech Wencel, Przepis na arcydzieło. Szkice literackie (Kraków: Arcana, 2003).
} 
Walicki: because we treat literature not only as a set of "texts in themselves," but as a space for reveal a certain experience of the world, whose space is a certain question that demands an answer coming from the present. ${ }^{45}$ I come back to the point I made a moment ago: what if the answer in question does not confirm the past? What if this answer is formulated in a completely different language than the language of the question, proving the discontinuity of culture? I consider it very valuable to reveal this situation with honesty: seeing that the language of the past is not my language, I see at the same time something that, for example, a researcher who, because of his profession, does not move into a distant past, for example, a historian of the most recent literature: for him culture is a continuity in fact confirmed by microscopic changes in poetics, languages, worldviews; for me, culture is a historical changeability of great paradigms (antiquitymodernity-postmodernity). Thanks to the separation from the past, I can include not only antiquity, but also modernity in their characteristics. By way of summary, the methods which Agnieszka Czechowicz calls "alternative" may be supplementary rather than antithetical with respect to such traditional methods of literary studies as philology. If philological hermeneutics is practiced within a horizon delineated by the language of the text and its original contexts, the "alternative" methods transcend the contexts and open the text not to the extrinsic but what is linked to it (not intentionally, but structurally). Only thanks to their use can we enter into a fully-fledged dialog with texts. There is no reason to be afraid of this: it does not deform the text (as it is open in itself to what its author did not anticipate), nor does it serve to expose the researcher's "I." Instead of harming culture, this dia$\log$ - or "active reception," as Hans Robert Jauss would say—keeps it alive: it treats texts not as separate worlds fulfilling themselves in their enclosure, but as "challenges," or questions that demand an answer from history. At the same time, the further we go into time, the more often a situation occurs in which the answers do not confirm the summons; in the case of the contemporary perception of Old Polish literature, the gap caused by modernity is responsible for the lack of such confirmation. Revealing this difference is again made possible by going beyond the original contexts: by immersing texts no longer in "alternative" methods, but in "alternative" views of the work that shape the cultural identity of the one who reads. This process is not something to be afraid of, either (much more harmful are the puerile

\footnotetext{
${ }^{45}$ See Paweł DyBEL, Granice rozumienia i interpretacji, 304.
} 
attempts to prove the "constant topicality," the "unfading beauty" or the "intellectual depth" of Old Polish literature). Thanks to this difference, we gain a background in which we can see more clearly both Old Polish culture and ourselves; thanks to this we are able to see more clearly the historical aspect of culture (and therefore changeability, instability, relativity) and of our cultural identities; thanks to this we can finally satisfy the postulate put forward by Agnieszka Czechowicz, i.e. extract beauty from old works; thanks to the cultural difference, beauty must nevertheless appear as a peculiar beauty: a beauty of otherness.

\section{BIBLIOGRAPHY}

Bohuszewicz, Paweł. "Po co literaturze dawnej współczesna teoria?" [Why would old literature need a contemporary theory?]. Litteraria Copernicana No. 2 (2008): 8-27.

BoHuszewicz, Paweł. “'Niezgodna niezgodność'. Metafora jako farmakon i nieudana próba wyjścia z impasu" ['Incompatible compatibility.' Metaphor as a pharmakon and a failed attempt to get out of the impasse]. Ruch Literacki No. 4-5 (2009): 313-25.

Borowski, Andrzej. Daniel Naborowski-wiersze wybrane [Daniel Naborowski-selected poems]. In Lektury polonistyczne. Średniowiecze-renesans-barok, vol. I, edited by Andrzej Borowski, Janusz S. Gruchała. Kraków: Uniwersitas, 1994.

BorowsKI, Andrzej. "Tendencje metodologiczne w najnowszych badaniach nad literaturą staropolską" [Methodological tendencies in the most recent studies on Old Polish literature]. Teksty Drugie No. 3 (1994): 78-83.

CHEMPEREK, Dariusz. 'Umyst przecię z swojego toru nie wybiega'. O poezji medytacyjnej Daniela Naborowskiego ['The mind is not running out of track.' On Daniel Naborowski's meditative poetry]. Lublin: Wydawnictwo UMCS, 1998.

CULLER, Jonathan. "In defence of overinterpretation." In Interpretation and Overinterpretation, edited by Stefan Collini. Cambridge: Cambridge University Press, 1998.

Czechowicz, Agnieszka. "Uwagi o przymusach metodologicznych w badaniach literatury staropolskiej" [Some remarks on the methodological compulsions in the study of Old Polish literature]. Roczniki Humanistyczne 56, issue 1 (2008): 7-16.

DerRIDA, Jacques. "The Pharmakon.” In idem, Dissemination. Translation with an introduction and additional notes by Barbara Johnson. London: The Athlone Press, 1981.

DerRIDA, Jacques. Of Grammatology. Translatedy by Gayatri C. Spivak. Baltimore: John Hopkins UP, 1997.

DyBel, Paweł. Granice rozumienia i interpretacji. O hermeneutyce Hansa-Georga Gadamera [The limits of understanding and interpretation. On the hermeneutics of Hans-Georg Gadamer]. Kraków: Uniwersitas, 2004.

Eco, Umberto. The Name of the Rose. Translated by William Weaver. Boston-New York: Mariner Books, 2014.

Eco, Umberto. "Between Author and Text." In Interpretation and Overinterpretation, edited by Stefan Collini. Cambridge: Cambridge University Press, 1998. 
FALĘCKA, Barbara. Sztuka tworzenia. Podmiot autorski w poezji kunsztownej polskiego baroku [The creative art. The authorial subject in the poetry of sophisticated Polish Baroque]. Wrocław: Zakład Narodowy im. Ossolińskich, 1983.

GolińSKI, Janusz K. Unitas et varietas. Szkice o piśmiennictwie polskiego baroku [Unitas et varietas. Essays on the literature of Polish Baroque]. Warszawa: Towarzystwo "Ogród Ksiąg," 2007.

GostyŃsKa, Dorota. Retoryka iluzji. Koncept w poezji barokowej [The rhetoric of illusion. The concept in Baroque poetry]. Warszawa: Instytut Badań Literackich PAN, 1991.

Hanusiewicz-LavalleE, Mirosława. "Współczesne metody badań nad staropolską literaturą religijną" [Contemporary methods of studies of Old Polish religious literature]. Roczniki Humanistyczne 56, issue 1 (2008): 17-37.

JAUSS, Hans Robert. "Proces literacki modernizmu od Rousseau do Adorna." Translated by Piotr Bukowski. In Odkrywanie modernizmu, edited and introduction by Ryszard Nycz. Kraków: Universitas, 2004.

JAUSS, Hans Robert. “Tradycja literacka a dzisiejsza świadomość nowoczesności” [Literary tradition and today's awareness of the modern]. In IDEM, Historia literatury jako prowokacja [Literary history as provocation], translated by Małgorzata Łukasiewicz, afterword Kazimierz Bartoszyński. Warszawa: Instytut Badań Literackich, 1999.

KalAGA, Wojciech. "Granice tekstu—mgławice tekstu" [The limits of text—the nebulae of text]. Teksty Drugie No. 4 (1998): 5-32.

KLEINER, Juliusz. "Historyczność i pozaczasowość w dziele literackim" [The historicity and timelessness in a literary work]. In IDEM. Studia z zakresu teorii literatury. Lublin: Towarzystwo Naukowe KUL, 1956.

KoEHLER, Krzysztof. "Kościół, reformacja, dialog” [Church, reformation, dialog]. Fronda No. 13/14 (1998): 28-47.

KoeHLER, Krzysztof. "Piotr Skarga, czyli witajcie w naszych czasach" [Piotr Skarga, or welcome to our times]. Fronda No. 9/10 (1997): 7-21.

KoEHLER, Krzysztof. "W rytmie godzinek, na rosyjskim trupie" [To the rhythm of a Marian prayer, on a Russian corpse]. Fronda No. 4/5 (1995): 287-307.

Koehler, Krzysztof. "Wstęp” [Introduction]. In 'Stuchaj mię, Sauromatha'. Antologia poezji sarmackiej, edited by Krzysztof Koehler. Kraków: Arcana, 2002.

Kotarska, Jadwiga. Erotyk staropolski. Inspiracje i odmiany [Old Polish erotic texts. Inspirations and variations]. Wrocław: Wydawnictwo PAN, 1980.

Lisicki, Paweł. "Mroczne dziedzictwo oświecenia" [The dark legacy of the Middle Ages]. In IDEM. Nie-ludzki Bóg. Eseje. Warszawa: Fronda, 1995.

MARKIEwICZ, Henryk. "Zrzędność bez przekory" [Grumpiness with no perversity]. Teksty Drugie No. 2 (1990): 91-98.

Markowski, Michał Paweł. "Dekonstrukcja” [Deconstructionism]. In Anna BurZYŃsKa, Michał P. Markowski. Teorie literatury XX wieku. Podręcznik, 369-72. Kraków: Znak, 2006.

Markowski, Michał Paweł. Nietzsche. Filozofia interpretacji [Nietzsche. The philosophy of interpretation]. Kraków: Uniwersitatis, $2001^{2}$.

Markowski, Michał Paweł. "Pieczołowite egzegezy i demoniczne użycia" [Meticulous exegeses and demoniacal uses]. In IDEM. Efekt inskrypcji. Jacques Derrida i literatura. Kraków: Homini, $2003^{2}$. 
MitoseK, Zofia. "Metoda filologiczno-historyczna" [The philological and historical method]. In EAM. Teorie badań literackich. Warszawa: Wydawnictwo Naukowe PWN, $1995^{3}$.

Mrowcewicz, Krzysztof. Trivium poetów polskich epoki baroku: klasycyzm-manieryzm-barok [The trivium of Polish Baroque poets: classicism—-mannerism-Baroque]. Kraków: Instytut Badań Literackich, 2005.

NowicKA-JEżowA, Alina. "Komparatystyka i filologia. Uwagi o studiach porównawczych literatury epok dawnych" [Comparative studies and philology. Comments on comparative literary studies in earlier eras]. In Polonistyka w przebudowie. Literaturoznawstwo-wiedza o językuwiedza o kulturze-edukacja. Zjazd polonistów, Kraków, 22-25 września 2004, edited by Małgorzata Czermińska et al., vol. II. Kraków: Universitas, 2005.

NyCZ, Ryszard. "O przedmiocie studiów literackich-dziś" [On the subject of literary studies today], in: Polonistyka w przebudowie. Literaturoznawstwo-wiedza o języku-wiedza o kulturze-edukacja. Zjazd polonistów, Kraków, 22-25 września 2004, edited by Małgorzata Czermińska et al., vol. I. Kraków: Uniwersitas, 2005.

OBREMSKI, Krzysztof. "Bitwa i polowanie w 'Kronice polskiej' Anonima zwanego Gallem. Relacje świata ludzkiego ze światem zwierząt" [Battles and hunting in the Polish Chronicle by Gallus Anonymus. Relations between human world and the animal one]. Pamiętnik Literacki No. 3 (2008): 5-18.

OBREMSKI, Krzysztof. “O intertekstualności badań historycznoliterackich” [On the intertextuality of studies in literary history], AUNC. Filologia Polska XLI (1993): 111-120.

PELC, Janusz. "Średniowiecze, renesans i barok w badaniach historycznoliterackich od roku 1918" [The Middle Ages, Renaissance and Baroque in studies in literary history since 1918]. In Rozwój wiedzy o literaturze polskiej po 1918 roku, edited and introduction by Janusz Maciejewski. Warszawa: Czytelnik, 1986.

SKWARCZYŃSKA, Stefania. Systematyka głównych kierunków $w$ badaniach literackich [Systematics of the main currents of literary studies], vol. I. Łódź: Łódzkie Towarzystwo Naukowe, 1948.

SŁAwIŃSKI, Janusz. "Analiza, interpretacja i wartościowanie dzieła literackiego" [Analysis, interpretation and valuation of a literary work]. In IDEM. Prace wybrane, edited by Włodzimierz Bolecki, vol. IV: Próby teoretycznoliterackie. Kraków: Universitas, 2000.

SZAHAJ, Andrzej. "Zwrot antypozytywistyczny dopełniony (zamiast wstępu)" [An anti-positivist turn completed (instead of an introduction). In Filozofia i etyka interpretacji, edited by Adam F. Kola, Andrzej Szahaj. Kraków: Universitas, 2007.

ULEwICZ, Tadeusz. "W staropolszczyźnie dzieją się rzeczy ważne (dorobek badawczy pokolenia)" [Major things are happening in Old Polish literature (the research legacy of a generation]. Ruch Literacki 7, No. 4 (1966): 161-77.

Wencel, Wojciech. Przepis na arcydzieto. Szkice literackie [A recipe for a masterpiece. Literary essays]. Kraków: Arcana, 2003.

WiLCZEK, Piotr. "Najnowsze tendencje w badaniach nad literaturą staropolską" [The newest tendencies in studies of Old Polish literature]. In IDEM, Polonice et Latine. Studia o literaturze staropolskiej, 13-30. Katowice: Wydawnictwo UŚ, 2007. 


\section{DANGEROUS LIAISONS, NECESSARY LIAISONS \\ ON THE “ALTERNATIVE” WAYS OF READING OLD POLISH TEXTS}

\section{Summary}

The article Dangerous liaisons, necessary liaisons. On the "alternative" ways of reading Old Polish texts is a polemic with Agnieszka Czechowicz's text Uwagi o przymusach metodologicznych $w$ badaniach literatury staropolskiej (Remarks on methodological compulsion in studies of Old Polish literature), in which so-called "alternative" methods (Deconstructionism, gender, etc.) of reading Old Polish texts are criticized on the basis of the assumption that they deform their true image. The present polemic uses a completely different assumption: there is nothing wrong in using methods coming from outside the context of the studied texts, for the works do not have a certain meaning in itself, but only an "osmotic" meaning. Textual "osmosis" is the almost infinite, but also limited by the semantic potential, openness of the text-not only to the contexts that the author foresaw, but also to the contexts that come from the commentator's culture, and to whose existence the "alternative methods" may draw our attention.

Key words: interpretation, philology, Deconstructionism, hermeneutics, text, osmosis.

Translated by Marcin Turski

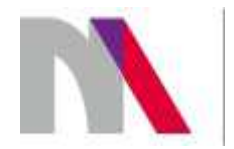

The preparation of the English version of Roczniki Humanistyczne (Annals of Arts) and its publication in electronic databases was financed under contract no. 836/P-DUN/2018 from the resources of the Minister of Science and Higher Education for the popularization of science. 